\title{
A hidden scale dependency in conserving working woodlands
}

Because plans for large-scale landscape preservation in the US do not rely exclusively on lands held in trust, conservation programs have a vested interest in forest stewardship by private landowners. Selective harvests for commercial sale are often highlighted as a financial incentive for owners of non-industrial "family forests" to sustainably maintain the working character of their acreage rather than subdivide it or convert it for development. However, the business costs inherent in even a small-scale commercial timber harvest typically mean that forest parcels smaller than approximately 80 acres are too small to support a financial return. Statistics for private forest ownership in the U.S. suggest this minimum scale makes commercial harvest incentives effectively inaccessible to more than $90 \%$ of forest owners. Rural landscape conservation and commercial timber harvests depend on the same economies of scale to be viable. Designs for regional-scale forest conservation need to account for non-industrial but nonetheless commercial economies of scale that set an inherent limit on financial incentives intended to foster stewardship activity among family-forest landowners. 


\section{A hidden scale dependency in conserving working woodlands}

Eli D. Lazarus ${ }^{1}$ and David Schaible ${ }^{2}$

${ }^{1}$ Environmental Dynamics Lab, Earth Surface Processes Research Group, School of Earth \& Ocean Sciences, Cardiff University, Cardiff, CF10 3AT, UK

${ }^{2}$ Timberland Consultants, PO Box 126, Nobleboro, Maine 04555, USA

Article Type: $\quad$ Commentary

Keywords: $\quad$ forest management; parcelisation; land use change

\section{Correspondence:}

Eli D. Lazarus

School of Earth \& Ocean Sciences

Cardiff University

Main Building, Park Place

Cardiff, CF10 3AT, UK

Tel: +44 (0)2920 875563

E-mail: LazarusED@cf.ac.uk 


\begin{abstract}
Because plans for large-scale landscape preservation in the US do not rely exclusively on lands held in trust, conservation programs have a vested interest in forest stewardship by private landowners. Selective harvests for commercial sale are often highlighted as a financial incentive for owners of non-industrial "family forests" to sustainably maintain the working character of their acreage rather than subdivide it or convert it for development. However, the business costs inherent in even a small-scale commercial timber harvest typically mean that forest parcels smaller than approximately 80 acres are too small to support a financial return. Statistics for private forest ownership in the U.S. suggest this minimum scale makes commercial harvest incentives effectively inaccessible to more than $90 \%$ of forest owners. Rural landscape conservation and commercial timber harvests depend on the same economies of scale to be viable. Designs for regional-scale forest conservation need to account for non-industrial but nonetheless commercial economies of scale that set an inherent limit on financial incentives intended to foster stewardship activity among family-forest landowners.
\end{abstract}




\section{Introduction}

Private forest land in the U.S. is being divided into smaller lots among more owners whose average ownership tenure is getting shorter (Butler 2008; White et al. 2008). Meanwhile, large-scale landscape conservation programs, such as one recently proposed for the New England region, where woodlands comprise the nation's largest intact forest corridor, rely on the aggregate stewardship practices of individual landowners (Foster et al. 2010). Although some argue that a lack of ecosystem awareness limits landowner engagement in conservation activities (Best 2004), others find that most woodlot owners already understand core concepts of ecosystem management (Rickenbach et al. 1998). If landowner preferences are not hindering large-scale landscape conservation efforts, then the major obstacles keeping landowners from choosing long-term stewardship over development are likely more practical than conceptual.

Carving large forest parcels into small ones is problematic because below a certain acreage, working woods become unworkable for any financial returnnot just for the landowner, but for the foresters, loggers, and haulers whose business is small-scale forestry. This threshold in parcel size is where landscape preservation and commercial forestry overlap: if a conservation plan needs landowners to manage their forests as woodlots, and a financial return from selective timber harvests is an incentive for landowners to participate, then the conservation plan is beholden to the same spatial economies of scale that are well known to commercial forestry practitioners (Row 1978; Cubbage 1983). 


\section{The business of non-industrial timber}

Economies of scale refer to an inverse relationship between the size of a commercial operation and its production costs. The fixed and variable costs of a timber harvest—including inventory, personnel, equipment, transport, and milling - are distributed over the area of land harvested. For an industrial timber company that controls vast areas of forest land, financial return is more limited by timber markets than by the quantity of acreage in the company's possession. But most private forest land in the U.S. belongs to non-industrial, "family-forest" owners whose holdings are orders of magnitude smaller than industrial tracts (Butler 2008).

Although a skilled consulting forester can estimate the financial return an owner might expect from a timber harvest, that evaluation is not obvious. Nonindustrial harvests operate through an attenuated, informal network of specialists. Typically, a harvesting operation begins when a landowner hires a forester, who grades the standing timber in the woodlot and contracts a logger to cut it. (Grade is a categorical assessment of timber value; prices per grade depend on the economic markets for wood.) The logger in turn contracts a hauler, and either the logger or the hauler has a contract with a sawmill. Independently, the mill grades the logs it receives, which may or may not match the forester's assessment. Based on the mill's grades, final payment ripples back through this chain of written, and sometimes verbal, contracts to the landowner. Although minimum operable parcel size depends to some extent on the market value of the timber, various studies (and the contributing author's 40 years of personal experience in 
the industry) suggest that most parcels smaller than 80 acres tend not to benefit from economies of scale, and parcels smaller than 20 acres are unlikely to yield any financial return (Row 1978; Cubbage 1983; Kittredge et al. 1996; Moldenhauer and Boulding 2009).

\section{The incentive vacuum}

This acreage threshold implies that a third of all U.S. family-forest acreageparcels divided into lots smaller than 50 acres—or approximately $11 \%$ of all U.S. forest land may be functionally too small for a commercial harvest (Fig. 1). In ownership terms, that means $90 \%$ of family-forest owners (Butler 2008) are likely to find the standard financial incentives of forest management, such as currentuse tax laws that assess forest land on the basis of its timber capacity rather than on its development potential, do not apply to them in practice. To qualify for the Tree Growth Tax Law in the state of Maine, for example, owners must have at least 10 acres and manage their land according to a plan for commercial harvest certified by a licensed forester (TGTL 2011). For many landowners, the personal satisfactions of green space, materials, firewood, and other incalculables make even the smallest forest parcels worthy of investment, but the apparent vacuum in forest-based financial incentives for small woodlots is consistent with, if not the explanation behind, survey data showing that owners of small parcels are unlikely to engage advice from a licensed forester (Butler and Leatherberry 2004). Unfortunately, unless a parcel grows particularly high-grade timber or is significantly larger than the minimum acreage for which a commercial harvest is 
viable, there is little actual financial incentive for a landowner to pursue the tax break and pay for consultations with a forester. The tax incentive is greatest for large parcels with high development potential, but often is not incentive enough: if these landowners decide to subdivide, parcelization creates management deserts in the same places that conservation needs spatially contiguous forests to flourish.

Well versed in the comparative advantages of large parcels, forestmanagement experts have long explored possible cooperative arrangements among landholders with adjoining properties (Cubbage 1983; Kittredge et al. 1996; Zhang et al. 2005; Moldenhauer and Boulding 2009), as well as ownernetwork approaches and finance strategies that include zoning and taxation amendments, targeted philanthropy, the creation of ecosystem markets, and other programs, many of which have been experimented with in the U.S. and other countries (Cubbage 1983; Foster et al. 2010). But even when owners are amenable to such cooperative designs, the economics of extant landmanagement structures appear to pre-empt widespread owner implementation and adoption (Klosowski et al. 2001; Kittredge 2005). Despite research-driven advocacy to strengthen property-tax incentives for family-owned working woodlands (Kilgore 2004; D'Amato et al. 2010; Foster et al. 2010), current-use tax incentives in rural landscapes are under political pressure as town budgets continue to weather the economic recession (Mistler 2012). Because land under conservation easement is typically exempt from property tax, critics contend that landscape-preservation measures reduce public revenues and drive up property 
taxes overall (Merenlender et al. 2004). As a result, conservation easements may be perceived as gentrification that excludes poorer landowners, a privileged option that passes the burden of property taxation onto those who cannot avoid it (McLaughlin 2002; Merenlender et al. 2004; Sandberg and Wekerle 2010).

\section{A new urgency}

Conservation programs still lack flexible financial rewards for stewardship that can compete with property taxes, health care costs, and real-estate development rights. These costs set the inexorable bottom line that many landowners live with—particularly "land rich, cash poor" owners, whose principal assets are invested in the land itself (Glascock 1978; McLaughlin 2002). To employ forestmanagement incentives in ways that support the maintenance of working rural landscapes, comprehensive conservation strategies will have to account for the practical scales of commercial timber systems. At critical risk are forest parcels of 100 acres and larger that ownership turnover and subdivision could render incapable of supporting sustainable timber management. If $90 \%$ of landowners hold only $11 \%$ of U.S. forest land, does it matter if those parcels get pulled beyond the reach of stewardship? After all, in the mid-19th century, conversion to farmland reduced forest cover in New England to 40\% (Foster et al. 2010). But the legacy of converting forest to farmland in the 19th century is fundamentally different from converting forest to house lots in the 21st. A new, scale-based calculus for incentives that nullify the financial disparity between stewardship and development on small parcels is increasingly urgent. Policy changes must make 
preservation an option available to all classes of landowners who want to keep their working woodlots both working and wooded, which in turn will help buttress conservation laws against reactionary political repeal.

\section{Acknowledgments}

This work was supported in part by the National Science Foundation (EPS0904155) and the University of Maine's Sustainability Solutions Initiative. Many thanks to P. Lazarus, V. Cleaves, and A. Payson.

\section{References}

Best, C. 2004. Non-governmental organizations: more owners and smaller parcels pose major stewardship challenges. Journal of Forestry 102:10.

Butler, B. J. 2008. Family Forest Owners of the United States, 2006. General Technical Report NRS-27. Northern Research Station, USDA Forest Service, Newton Square, Pennsylvania.

Butler, B. J. and E. C. Leatherberry, E. C. 2004. America's family forest owners. Journal of Forestry 102:1-9.

Cubbage, F. 1983. Economics of forest tract size: theory and literature. General Technical Report SO-41. Southern Forest Experiment Station, USDA Forest Service, New Orleans, Louisiana.

D'Amato, A. W., P. F. Catanzaro, D. T. Damery, D. B. Kittredge, and K. A. Ferrare. 2010. Are family forest owners facing a future in which forest management is not enough? Journal of Forestry 108:32-38.

Foster, D. R., et al. 2010. Wildlands and woodlands: a vision for the New England landscape. Harvard Forest, Harvard University, Petersham, Massachusetts.

Glascock, H. R., Jr. 1978. The view from here. Journal of Forestry 76:268-312.

Kilgore, M. A. 2004. Public forest policies and the family forest. Journal of Forestry 102:11. 
Kittredge, D. B. 2005. The cooperation of private forest owners on scales larger than one individual property: international examples and potential application in the United States. Forest Policy and Economics 7:671-688.

Kittredge, D. B., M. J. Mauri, and E. J. McGuire. 1996. Decreasing woodlot size and the future of timber sales in Massachusetts: when is an operation too small? Northern Journal of Applied Forestry 13:96-101.

Klosowski, R., Stevens, T., Kittredge, D. and Dennis, D. (2001). Economic incentives for coordinated management of forest land: a case study of southern New England. Forest Policy and Economics 2:29-38.

McLaughlin, N. A. 2002. The role of land trusts in biodiversity conservation on private lands. Idaho Law Review 38:453-469.

Merenlender, A. M., L. Huntsinger, G. Guthey, and S. K. Fairfax. 2004. Land trusts and conservation easements: who is conserving what for whom? Conservation Biology 18:65-75.

Mistler, S. 2012. Maine's tree growth law gives massive tax breaks to landowners big and small. The Sun Journal (Lewiston, Maine), 15 April 2012.

Moldenhauer, M. C. and M. C. Bolding. 2009. Parcelization of South Carolina's private forestland: loggers' reactions to a growing threat. Forest Products Journal 59:37-43.

Rickenbach, M. G., D. B. Kittredge, D. Dennis, and T. Stevens. 1998.

Ecosystems management: capturing the concept for woodland owners. Journal of Forestry 96:18-24.

Row, C. 1978. Economies of tract size in timber growing. Journal of Forestry 76:576-582.

Sandberg, L. A. and G. R. Wekerle. 2010. Reaping nature's dividends: the neoliberalization and gentrification of nature on the Oak Ridges Moraine. Journal of Environmental Policy and Planning 12:41-57.

The Maine Tree Growth Tax Law (TGTL). Information Sheet \#17 (Law 36 MRSA $\S 571-584 A$ ). Maine Forest Service, Augusta, Maine, revised April 2011.

White, E. M., and R. Mazza. 2008. A closer look at forests on the edge: future development on private forests in three states. General Techical Report PNWGTR-758, Pacific Northwest Research Station, USDA Forest Service, Portland, Oregon. 
Zhang, Y., D. Zhang, and J. Schelhas. 2005. Small-scale non-industrial private forest ownership in the United States: rationale and implications for forest management. Silva Fennica 39:443-454.

Figures \& Figure Legends

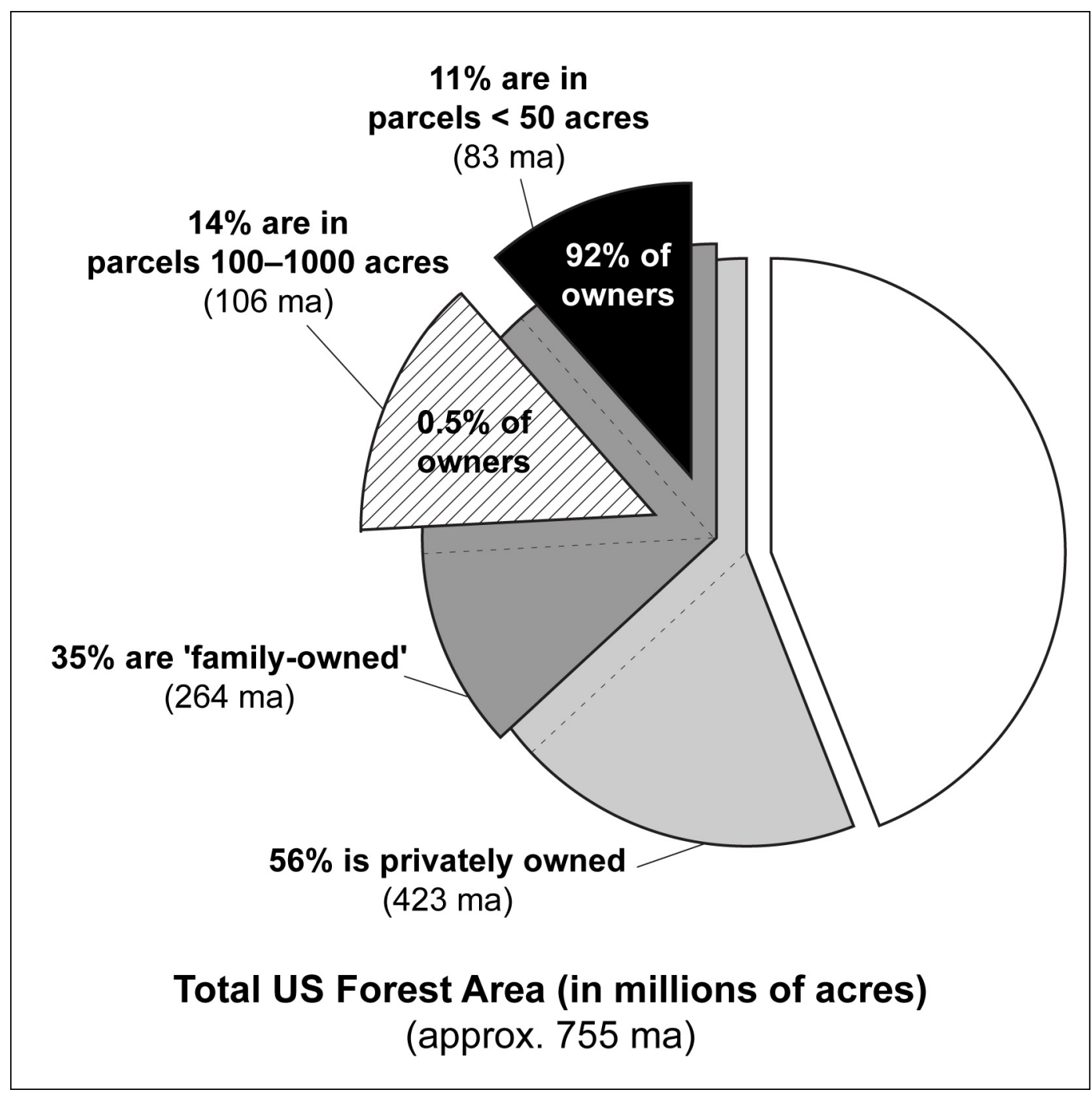

Figure 1. Key subcategories of forest subdivision and ownership in the US, using data compiled from Butler (2008). Of all privately owned, non-industrial forest land, $11 \%$ is in parcels smaller than 50 acres (black wedge), and therefore below the minimum size typically necessary to support a commercial harvest. This acreage category accounts for $90 \%$ of all private forest land owners. 